Acta vet. scand. $1987,28,15-22$.

From the Department of Pathology, Norwegian College of Veterinary Medicine, and

the Department of Pathology, The Norwegian Radium Hospital and Institute for Cancer Research,

Oslo, Norway.

\title{
Brain and Spinal Cord Lesions in Encephalitozoonosis in the Blue Fox
}

\author{
By Inge Bjerkås and Jahn M. Nesland
}

\begin{abstract}
Bjerkås, I. and J. M. Nesland: Brain and spinal cord lesions in encephalitozoonosis in the blue fox. Acta vet. scand. 1987, 28, 15-22. - The central nervous system lesions in encephalitozoonosis were studied in 11 naturally infected blue foxes. Immunohistochemical staining was employed in the demonstration of the parasites and identification of host cells. Consistent findings in acute to subacute stages included granulomatous meningoencephalomyelitis and vasculitis, with arterial lesions similar to polyarteritis nodosa. Chronic stages were dominated by arteriosclerosis, perivascular mononuclear infiltrations and gliosis, with less prominent granulomatous reaction. Parasites were almost constantly observed in association with active lesions both in vessels and nervous tissue. Parasitophorous vacuoles (PV) occurred in endothelial cells and in the medial layer of arteries. Neurons, including even their processes, were widely parasitized, a fact that may account for the brain being an important target organ. PV also occurred in ependymal cells of the choroid plexus and occasionally in macrophages. A great number of parasites was demonstrated in phagolysosomes of macrophages, a fact that probably reflects a relative resistance to digestion, and may consequently contribute to the development of the prominent granulomatous reaction. It was concluded that the brain lesions, except in chronic stages of mild infections, seem to be pathognomonic for encephalitozoonosis in the blue fox.
\end{abstract}

Encephalitozoon cuniculi; central nervous system; pathomorphological changes; immunohistochemistry.

Encephalitozoon cuniculi is an obligate, intracellular, microsporidian parasite with a direct life cycle. It has world-wide distribution and can probably infect all mammalian species (Wilson 1979), and even birds (Kemp \& Kluge 1975, Poonacha et al. 1985). Although most infections usually run a subclinical course, there are several reports of severe illness and death in young carnivores. Signs of involvement of the central nervous system (CNS) usually predominate (Van Rensburg \& du Plessis 1971, Nord- stoga 1972, Shadduck et al. 1978, Botha et al. 1979). The farmed blue fox (Alopex lagopus) appears to be one of the most susceptible species. Experimental studies and data obtained from spontaneous encephalitozoonosis in the blue fox have both provided evidence that clinically apparent disease is a result of foetal infection (Nordstoga 1972, Mohn et al. 1974 and 1982).

Although vessels of any organ may be affected, the brain and kidneys generally appear to be the major target organs in naturally 
infected blue foxes (Nordstoga \& Westbye 1976). Extensive extravascular lesions are seen in the kidneys, in which the tubular cells are parasitized. The pathogenesis of the CNS lesions has not been established. However, knowledge of the nature of the pathological lesions may be essential to the pathologist in differentiating encephalitozoonosis from other infections with involvement of the CNS, as causative organisms can be sparse or even absent in chronic stages.

This report presents a pathomorphological study of brain and spinal cord lesions in spontaneous encephalitozoonosis in young blue foxes. Pathogenesis and differential diagnoses are discussed.

\section{Material and Methods}

CNS material from 11 blue foxes with spontaneous encephalitozoonosis was examined by light microscopy. Etiological diagnosis was based on the histological demonstration of typical organisms reacting immunohistochemically with antiserum to E. cuniculi (Bjerkås \& Landsverk 1986). The animals were 2-5 $1 / 2$ months of age and came from 2 different farms. The cases from farm I, aged 2-3 months, were obtained for necropsy during a period of high mortality rate among the pups. Signs of CNS dysfunction predominated. The animals from Farm II were obtained some time after an outbreak of encephalitozoonosis had culminated, and were 4-5 1/2 months of age. Some affected animals, including the present cases, had survived with persistent neurological signs. Two of the foxes from Farm I were admitted for necropsy in the frozen state. In the other cases the material was fixed immediately after the foxes had been killed. The brain was examined in all cases, and the spinal cord in the 5 cases from Farm I.

Material was fixed in $10 \%$ buffered formalin and subsequently embedded in paraffin. Sec- tions were stained with hematoxylin and eosin (H \& E), toluidine blue, modified Gram's method (Petri 1969), elastin van Gieson, methyl green-pyronin, periodic acid schiff (PAS), the Martius scarlet blue method (MSB), phosphotungstic acid-hematoxylin method (PTAH), luxol fast blue, and the Bodian method.

Formalin-fixed, paraffin-embedded material was also used for immunohistochemical studies. The avidin-biotin-peroxidase-complex (ABC) method was applied ( $H s u$ et al. 1981), using antisera raised against E. cuniculi, Toxoplasma gondii, protein S-100, neuron-specific enolase (NSE), glial fibrillary acid protein (GFAP), lysosyme, $\alpha-1$ antitrypsin and $\alpha-1$-antichymotrypsin (Table 1). Deparaffinized sections were treated for $30 \mathrm{~min}$ with $0.3 \%$ hydrogen peroxide $\left(\mathrm{H}_{2} \mathrm{O}_{2}\right)$ in methanol for block endogenous peroxidase, and then incubated for $20 \mathrm{~min}$ with normal nonimmune serum diluted in $25 \%$ bovine serum albumin (BSA) to eliminate nonspecific staining. Excess normal serum was blotted from the slides before incubation with the specific primary antiserum for $30 \mathrm{~min}$ at room temperature or $18-22 \mathrm{~h}$ at $4^{\circ} \mathrm{C}$ (Table 1). The sections were then incubated with a 1:200 dilution of biotin-labelled secondary antibody for $30 \mathrm{~min}$, and $\mathrm{ABC}$ reagent $(10 \mu \mathrm{g} / \mathrm{ml}$ avidin and 2.5 $\mu \mathrm{g} / \mathrm{ml}$ biotin-labelled peroxidase) for $60 \mathrm{~min}$ (Vector Laboratories, Burlingame, California). Tissues were stained for $5 \mathrm{~min}$ with $0.05 \%$ 3'3-diamino benzidine tetra hydrochloride freshly prepared in $0.05 \mathrm{~mol} / \mathrm{l}$ Tris buffer, pH 7.6, containing $0.01 \% \mathrm{H}_{2} \mathrm{O}_{2}$, and then counterstained with hematoxylin, dehydrated and mounted.

All dilutions of antisera, biotin-labelled secondary antibody and $\mathrm{ABC}$ reagent were made with $12.5 \%$ BSA as the diluent. Control studies included staining of relevant positive controls and a negative control in 
Inge Bjerkås and Jahn M. Nesland: Brain and Spinal Cord Lesions in Encephalitozoonosis in the Blue Fox.
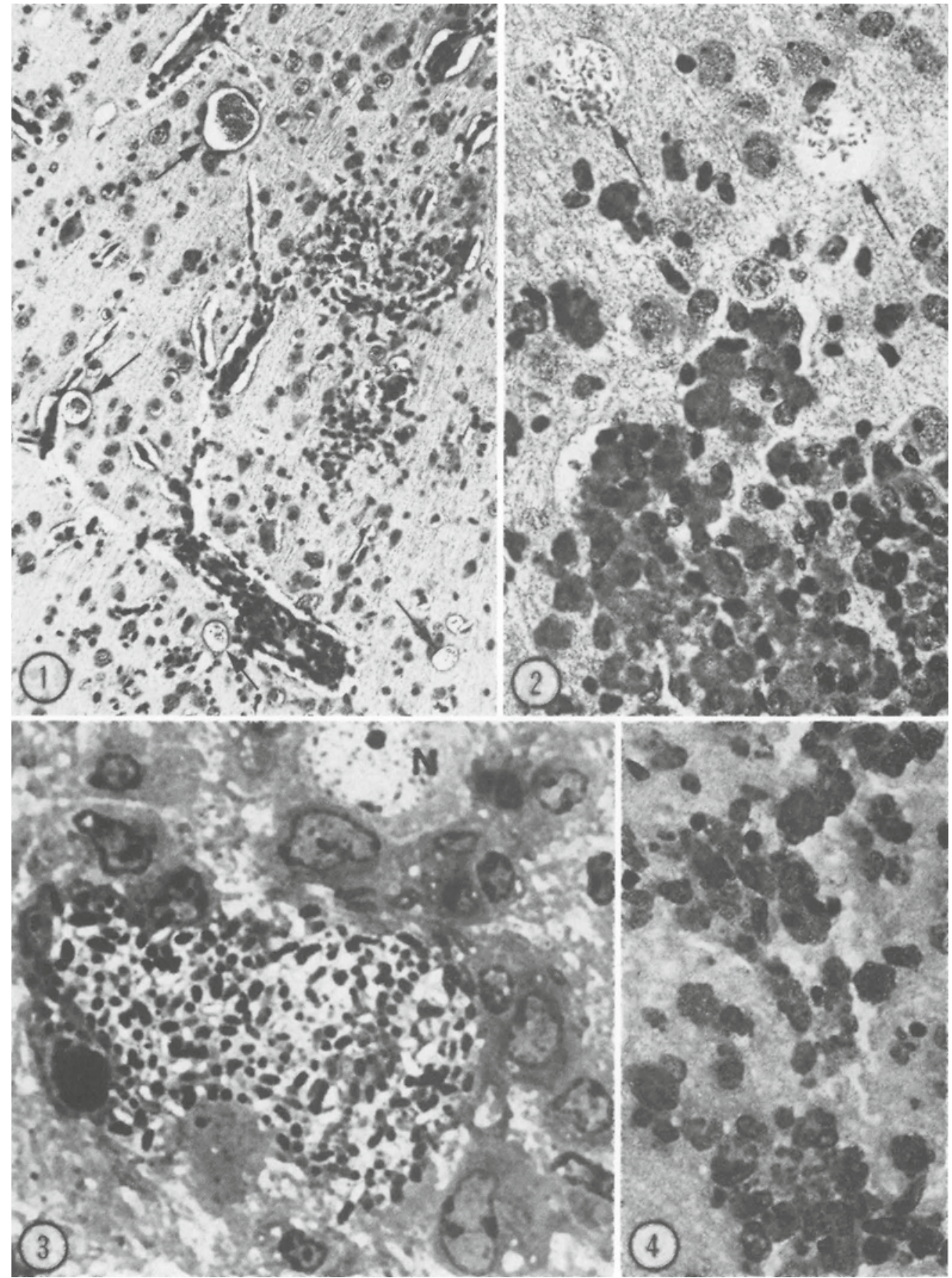
Figure 1. Granulomatous inflammation and perivascular cuffing in cerebral cortex. Parasitophorous vacuoles are indicated by arrows. Hematoxylin and eosin. $\times 170$.

Figure 2. Positive staining for lysosyme surrounding individual phagocytized parasites in cerebral granuloma. Two parasitophorous vacuoles are indicated by arrows. $\mathrm{ABC}$ procedure, counterstained with hematoxylin. $\times 680$.

Figure 3. Macrophages surrounding parasites that are probably in the process of being released from degenerated host cell in the brain stem. N, neuron. Epon section, toluidine blue. $\times 1700$.

Figure 4. Positive staining for $\alpha-1$-antitrypsin surrounding parasites in macrophages; brain stem. ABC procedure, counterstained with hematoxylin. $\times 680$.

Figure 5. Neuron with numerous parasites in perikaryon $(\mathrm{P})$ and processes (arrows); brain stem. Toluidine blue. $\times 680$.

Figure 6. Parasitized neurons in a ventral horn of the spinal cord. Hematoxylin and eosin. $\times 420$.

Figure 7. Cerebellar granuloma with many phagocytized parasitic spores (arrowheads). The faintly stained structures (small arrows) are probably partly degraded spores. A parasitophorous vacuole (large arrow) containing developmental stages is seen in a cell with the features of a macrophage. Epon section, toluidine blue. $\times 1700$.

Figure 8. Immunostaining for neuron-specific enolase (NSE) in the spinal cord. A positive reacting rim (arrow) is surrounding a parasitophorous vacuole, suggesting that the host cell is a neuron. $\mathrm{N}$, positively stained unaffected neuron. $\mathrm{ABC}$ procedure, counterstained with hematoxylin. $\times 680$.

Figure 9. Parasitophorous vacuole within the medial layer of a meningeal artery (arrows). The parasites are reacting with anti-Encephalitozoon serum. ABC procedure, counterstained with hematoxylin. $\times 680$.

Figure 10. Parasitophorous vacuole (arrow) containing developmental stages, in an endothelial cell of a small vessel in the cerebellum. The vessel is surrounded by macrophages with phagocytized parasites (arrowheads). Epon section, toluidine blue. $\times 1700$.

Figure 11. Parasitophorous vacuoles (arrows) both in intima and media of a meningeal artery with perivascular granulomatous reaction. Epon section, toluidine blue. $\times 680$.

Figure 12. Meningeal artery with necrosis associated with parasites and perivascular inflammatory reaction. A parasitophorous vacuole is indicated by an arrow. Hematoxylin. $\times 420$.

Figure 13. Chronically changed meningeal artery with intimal proliferation, luminal narrowing, splitting of internal elastic lamina and adventitial mononuclear infiltrations. A necrotic area is indicated.by an arrow. Elastin van Gieson. × 170. 


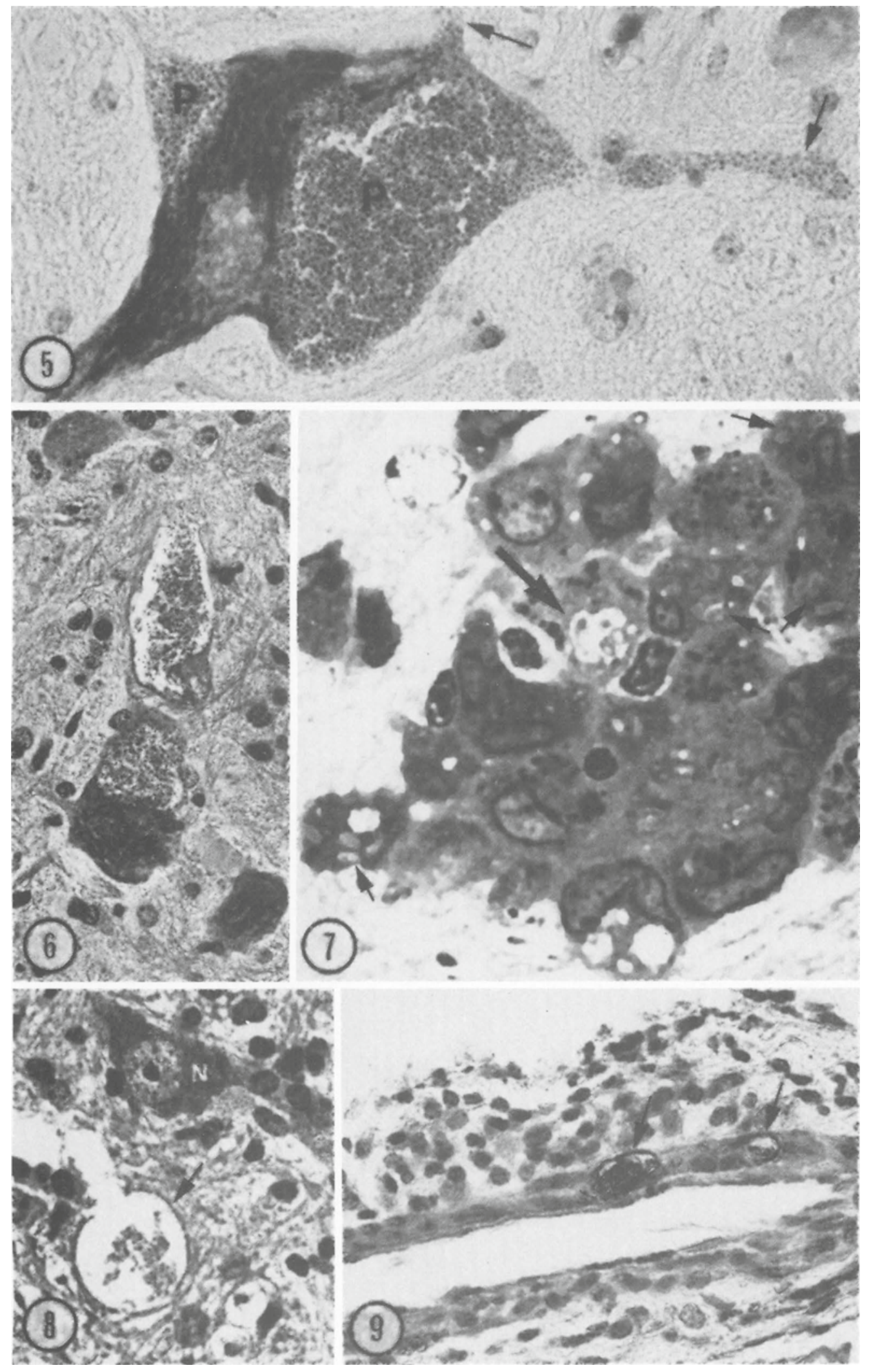




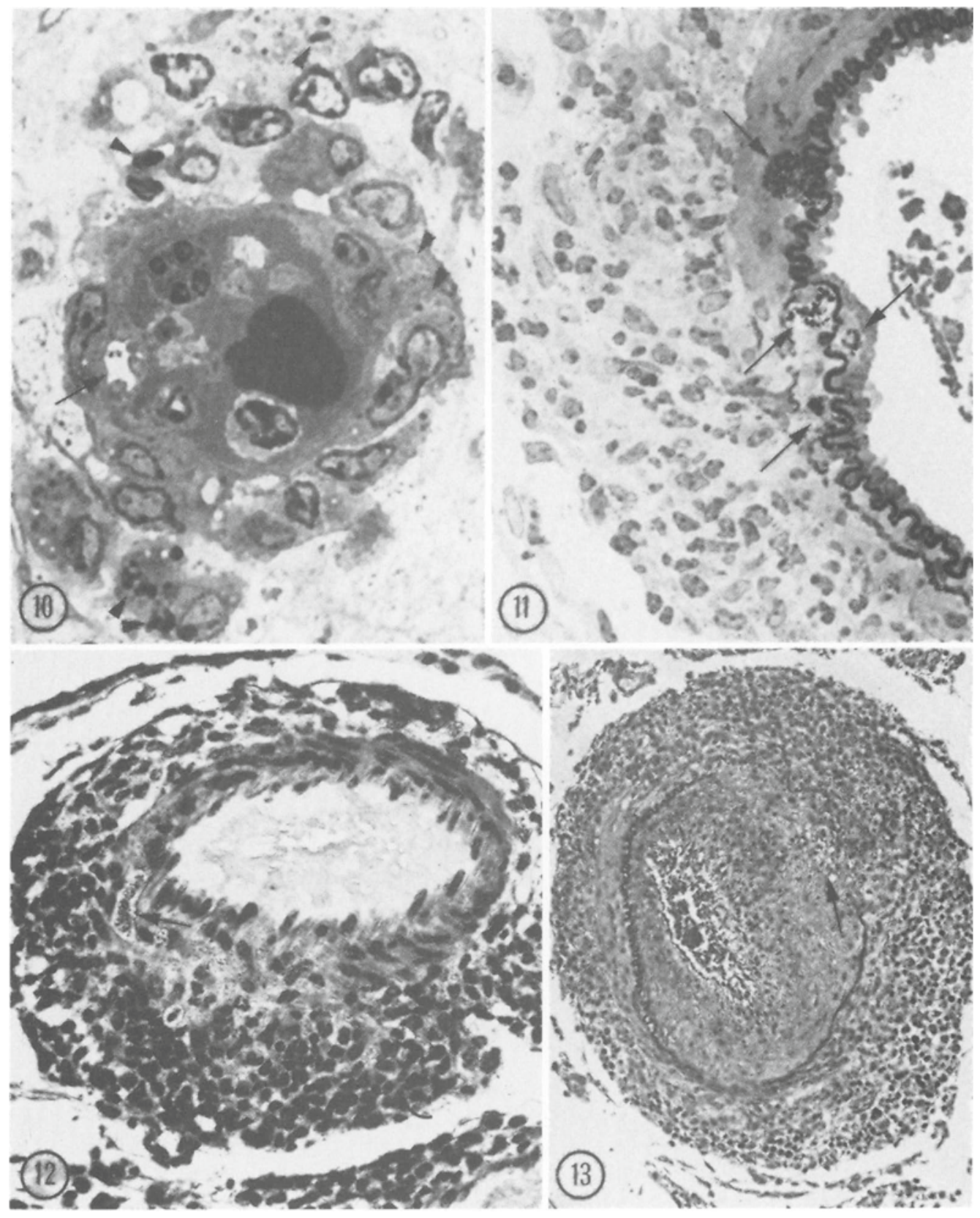


Table 1. Primary antisera.

\begin{tabular}{|c|c|c|c|}
\hline $\begin{array}{l}\text { Antisera raised } \\
\text { against }\end{array}$ & Dilution & $\begin{array}{l}\text { Incubation time } \\
\text { and temperature }\end{array}$ & Source \\
\hline $\begin{array}{l}\text { Encephalitozoon } \\
\text { cuniculi }\end{array}$ & $1: 1800$ & $\begin{array}{l}30 \mathrm{~min} \text {, } \\
\text { room temperature }\end{array}$ & Testmann A/S \\
\hline Toxoplasma gondii & $1: 600$ & $"$ & $\begin{array}{l}\text { Norwegian Defence } \\
\text { Microbiological Lab. }\end{array}$ \\
\hline $\begin{array}{l}\text { Glial fibrillary } \\
\text { acid protein (GFAP) }\end{array}$ & $1: 16$ & $18-22 \mathrm{~h}$ & Dako Comp. \\
\hline $\begin{array}{l}\text { Protein S-100 } \\
\text { Neuron-specific }\end{array}$ & $1: 700$ & " & , \\
\hline enolase (NSE) & $1: 1000$ & $"$ & " \\
\hline$\alpha$-1-antitrypsin & $1: 100$ & $\begin{array}{l}30 \mathrm{~min} \text {, } \\
\text { room temperature }\end{array}$ & $"$ \\
\hline$\alpha-1$-antichymotrypsin & $1: 200$ & " & " \\
\hline Lysosyme & $1: 100$ & ” & , \\
\hline
\end{tabular}

which the primary antibody was replaced by a nonimmune serum.

Small specimens from 3 cases (Farm I) were fixed in $3 \%$ buffered glutaraldehyde, postfixed in osmium tetroxide, dehydrated in alcohols and embedded in Epon. Semi-thin sections were stained with toluidine blue and used for light microscopical examinations.

\section{Results}

Gross lesions

There was excess serous fluid in the subdural space in all cases. Five of the cases from Farm II exhibited dilation of all brain ventricles. One of these had hemorrhages into the lateral ventricles and subarachnoidal space of the brain stem.

\section{Light microscopy}

The cases could be divided into 2 groups, one comprising the cases from Farm I with acute to subacute lesions, the other including those from Farm II with predominantly chronic changes.
Acute to subacute changes. The cases in this group exhibited extensive, active lesions in all parts of the brain and spinal cord, and numerous parasites, most of which were $1 \times 2.5 \mu \mathrm{m}$ in size, with rounded ends. Immunostaining with antiserum against E. cuniculi revealed a distinct brown colour (Fig. 9), while no reaction was observed with antiserum against Toxoplasma gondii. Antiserum against $\alpha$-1-antichymotrypsin also stained the parasites in addition to lysosomal material.

Many parasites were enclosed in parasitophorous vacuoles (PV) of host cells. However, an even greater number occurred in phagolysosomes of macrophages. These were surrounded by a positively stained halo when antisera against lysosyme, $\alpha$-1-antitrypsine and $\alpha$-1-antichymotrypsine were used (Figs. 2 and 4). In addition, scattered parasites within a limited area, and probably originating from ruptured PV, were occasionally observed.

The parasites were stained faintly with $\mathrm{H}$ \& E. The modified Gram's method provided a 
distinct staining of parasites in PV, while in the macrophages only a moderate number was stained compared with the results of immunostaining for E. cuniculi.

Though proliferative stages could hardly be distinguished in paraffin-sections, they were readily demonstrated, although faintly stained, in Epon-sections stained with toluidine blue (Figs. 7 and 10). However, the spores of the PV were intensely stained. In macrophages, many inclusions of the same size and shape were stained very faintly and probably represented partly degraded spores (Figs. 7 and 10).

The greatest PV measured $80 \mu \mathrm{m}$ in diameter and consisted mainly of spores, while the smallest PV contained mainly or exclusively proliferative stages (Figs. 7 and 10). Most PV were spherical, but some were elongated or had several protrusions. Some host cells apparently contained more than one PV. A definite cyst wall was never observed.

Attempts were made to identify the host cells, and the results are summarized in Table 2. Many PV were associated with blood vessels in the meninges and nervous tissue of brain and spinal cord (Figs. 9-12).

Table 2. Types of parasitized cells.

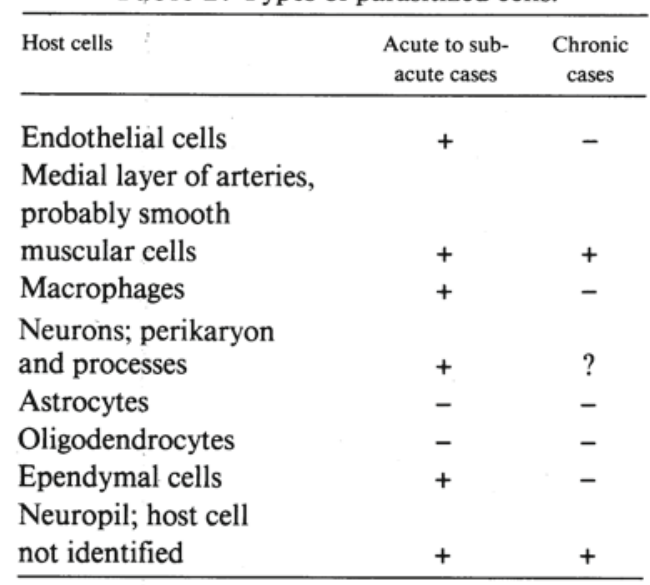

They occurred in endothelial cells of all types of vessel (Fig. 10). Capillaries in the nervous tissue were frequently parasitized. In arteries, numerous PV were seen in the medial layer, and were probably located in smooth muscle cells (Figs. 9, 11 and 12). In the grey matter, however, many PV were observed in the cell body and even in the processes of neurons (Figs. 5 and 6), a fact that was most readily demonstrated in the great neurons of the brain stem and ventral horns of the spinal cord. Purkinje cells in the cerebellum were also parasitized. In addition, there were many host cells the identity of which could not be determined, as visible cytoplasm was extremely scanty or degenerated (Figs. 1-3). With antiserum to NSE, however, a positively reacting rim surrounded several PV, suggesting that the host cells were neurons (Fig. 8). A few PV were seen in ependymal cells of the choroid plexus. However, parasites were not definitely recognized in other glial cells positive for GFAP or protein S-100. In semi-thin Eponsections, PV were occasionally observed in cells exhibiting the features of macrophages (Fig. 7).

Pathological lesions were observed at all levels of brain and spinal cord, including the choroid plexus and the meninges. A granulomatous inflammation was the most striking feature in all cases of this group (figs. 1, 2, 4 and 7). Although no special predilection area was observed, the grey matter, and the cerebral cortex in particular, was more severely affected than the white matter. In the cerebellar cortex, the lesions were most prominent in the molecular and Purkinje layers. In the spinal cord, severe lesions, mostly confined to grey matter, occurred in some sections, while only minor lesions were observed in others.

The meninges were almost always diffusely infiltrated with inflammatory cells, parti- 
cularly macrophages, lymphocytes and plasma cells. There was a marked perivascular reaction, frequently with granulomatous inflammation. Although any type of vessel could be affected, the most dramatic lesions occurred in arteries, particularly of the meninges (Figs. 11-12). The lesions ranged from minor degeneration of intima and/or media to fibrinoid necrosis that caused considerable thickening of the wall. Thrombosis was only occasionally observed. The changes were usually confined to segments, and in many vessels only a part of the circumference was affected. Necrotic areas were infiltrated with polymorphonuclear leucocytes, and a massive granulomatous reaction surrounded the affected area of the vascular wall. Parasites, at least those in macrophages, were always observed in association with affected vessels.

Capillaries and other small vessels in affected areas of nervous tissue were prominent, with hypertrophied endothelial cells and intravascular accumulation of leucocytes. Mononuclear perivascular cuffings were frequent, and many vessels were surrounded by granulomatous reaction.

Multiple granulomas with no apparent association to vessels were frequently seen in the nervous tissue. The epitheloid-shaped macrophages were intermingled with polymorphonuclear leucocytes, lymphocytes and plasma cells. Numerous parasites, apparently located in phagosomes, were seen within the macrophages in both granulomas and perivascular cuffings (Figs. 2, 4, 7, and 10). Granulomas sometimes exhibited central necrosis in which free parasites were occasionally observed. Ruptured PV with released parasites without surrounding inflammatory reaction were infrequently present. Various degrees of neuronal and nerve fibre degeneration, along with oedema, were usu- ally associated with the inflammatory lesions. Some areas in the white matter exhibited status spongiosus and marked gliosis. However, extensive necroses were infrequent.

Chronic changes. In these cases, parasites were very few, and PV were only seen in nervous tissue and the medial layer of meningeal arteries (Table 2). Phagocytized parasites were rarely observed. The subarachnoidal space was widened, but meningeal inflammatory infiltrations were sparse, except in perivascular areas. In meningeal arteries, sclerotic changes with intimal thickenings and luminal narrowing, splitting of the internal elastic membrane and adventitial mononuclear infiltrations, were the most prominent changes (Fig. 13). Some arteries were completely obliterated. The medial and adventitial layer exhibited various degrees of scarring. Also foci of active lesions and fibrinoid necrosis occurred in a few chronically changed arteries. Perivascular cuffing, in which lymphocytes and plasma cells were the predominant cell types, was the most prominent change in the vessels in nervous tissue. Granulomatous reactions also occurred, though parasites were infrequent in these. However, most macrophages had less abundant cytoplasm and were intermingled with microglial cells without clear phagocytic features. In addition, astrocytes and plasma cells represented a greater part of the cell population. Frequently, a diffuse astrocytic and microglial hyperplasia occurred in adjacent tissue. In some cases granulomas were infrequent, and multifocal and diffuse microglial and astrocytic proliferation, together with vascular changes and plasma cell infiltration, were the most conspicuous lesions. Some cases exhibited marked atrophy in areas of the cerebral cortex, with neuronal paucity and diffuse gliosis. 


\section{Discussion}

The present study shows that parasitism of cells of the nervous tissue is of considerable pathogenetic significance in brain and spinal cord lesions in encephalitozoonosis in the blue fox. This is apparently the first report demonstrating that neurons, and even their processes, are widely parasitized. These observations may explain the fact that the brain together with the kidneys, is a major target organ (Nordstoga 1972).

The great number of parasites in macrophages indicates that the parasites are degraded very slowly, and consequently represent a persistent intracellular irritant. This may account for the extensive granulomatous reaction with development of epithelioid cells (Robbins \& Cotran 1979), a prominent feature in encephalitozoonosis in various animal species.

In the present cases, vascular lesions were consistent with those previously reported both in the blue fox and dog (Nordstoga 1972, McCully et al. 1978). Nordstoga \& Westbye (1976) found that the arterial lesions recognized in a variety of organs in the blue fox, were morphologically equivalent to classical polyarteritis nodosa. The pathogenetic mechanism of these lesions is not known, but a hypersensitivity reaction has been assumed. In canine encephalitozoonosis, however, Van Dellen et al. (1978) suggested that the necrotic vasculitis mainly resulted from vascular ischaemia due to occlusion by parasitized endothelial cells. Occlusion of the tiny vasa vasorum might accordingly cause necrosis in the arterial walls. The present study in the blue fox, may support the assumption that the lesions are caused by a hyperimmune condition. Parasites were regularly found in association with acute lesions and seemed to be comparatively resistant to degradation. Previous studies have shown the strong antigenic properties of the parasite (Mohn 1982).

The positive staining of the parasites with antiserum against $\alpha$-1-antichymotrypsin is an interesting observation. However, the possibility that the rabbit in which the antiserum was raised, was infected with E. cuniculi cannot be excluded, as encephalitozoonosis is a common infection in laboratory rabbits.

The presence of PV devoid of inflammatory response, and the almost total lack of free or phagocytized parasites in the chronic stages, may possibly suggest a kind of parasite-host "compromise", with persistent PV. However, no definite cyst stages such as those found in the cyst-forming coccidia, have ever been demonstrated in encephalitozoonosis (Shadduck \& Pakes 1971).

Nearly all mammalian microsporidian pathogens so far investigated, appear to belong to the genus Encephalitozoon (Montrey et al. 1973, Barker 1975, Pakes et al. 1975, Botha et al. 1979, Mohn et al. 1981, Pang \& Shadduck 1985). In addition, it seems likely that only one species is involved. As stated by other authors, E. cuniculi is readily distinguishable from $\mathrm{T}$.gondii and several other protozoa on the basis of different morphology and staining properties (Moller 1968, Koller 1969, Shadduck \& Pakes 1971). This is also true for a Toxoplasmalike parasite that was experimentally transmitted into a blue fox from a dog (Bjerkås et al. 1984). Immunohistochemical methods have provided an even more specific tool for identification of the parasites considered here (Bjerkås \& Landsverk 1986).

Although the CNS lesions in toxoplasmosis may be similar to those of encephalitozoonosis in several respects (Fankhauser 1963, Shadduck \& Pages 1971), polyarteritis nodosa has not been reported to occur in 
toxoplasmosis, and granulomatous formations are probably less prominent. Vascular lesions have been reported in calves (Hansen \& Mostafa 1956) and in lambs (Landsverk \& Bratberg 1979) with sarcocystosis, but tissue cysts of Sarcocystis spp. are not known to occur in the fox. Fox encephalitis, an acute, usually fatal, viral infection affecting vessels of CNS, must also be considered. However, lesions are restricted to endothelial damage and hemorrhages, without significant inflammatory lesions (Innes \& Saunders 1962). The fox is also susceptible to canine distemper. However, demyelination is the salient feature of this infection (Dungworth 1985). It may therefore be concluded that a picture with marked vasculitis and polyarteritis nodosa combined with prominent microgranulomas in the CNS is in most cases pathognomonic for encephalitozoonosis in the blue fox, even when parasites are not evident. However, in the chronic stages of mild infections, lesions may be nonspecific.

\section{References}

Barker RJ: Ultrastructural observations on Encephalitozoon cuniculi Levaditi, Nicolau et Schoen, 1923, from mouse peritoneal macrophages. Folia Parasitologica (Praha) 1975, 22, 1-9.

Bjerkås I, Mohn SF, Presthus J: Unidentified cyst-forming sporozoon causing encephalomyelitis and myositis in dogs. Z. Parasitenkd. 1984, 70, 271-274.

Bjerkås I, Landsverk $T$ : Identification of Toxoplasma gondii and Encephalitozoon cuniculi by immunoperoxidase techniques and electron microscopy, in stored, paraffin-embedded, formalin-fixed tissue. Acta vet. scand. 1986, 27, $11-22$.

Botha WS, Van Dellen AF, Stewart CG: Canine encephalitozoonosis in South Africa. J. S. Afr. vet. Ass. 1979, 50, 135-144.
Dungworth $D L$ : The respiratory system. In: Jubb KVF, Kennedy PC \& Palmer N (eds.) Pathology of Domestic Animals. Vol. II. Academic Press, Orlando, San Diego, New York, London, Toronto, Montreal, Sidney, Tokyo, 1985.

Fankhauser R: Polymyositis und Encephalomyelitis granulomatosa toxoplasmica beim Hund. Schw. Arch. Tierheilkd. 1963, 105, 688-699.

Hansen H-J, Mostafa MSE: Bovine periarteritis nodosa. Vet.-Med. J. (Cairo) 1956, 3, 57-67.

Hsu SM, Raine L, Fanger H: A comparative study of the peroxidase-antiperoxidase method and an avidin-biotin complex method for studying polypeptide hormones with radioimmunoassay antibodies. Amer. J. clin. Path. 1981, 75, 734-738.

Innes, JRM, Saunders LZ: Comparative Neuropathology. Academic Press, New York, London, 1962.

Kemp, RL, Kluge JP: Encephalitozoon sp. in the blue-masked lovebird, Agapornis personata (Reichenow): First confirmed report of microsporidian infection in birds. J. Protozool. 1975, 22, 489-491.

Koller LD: Spontaneous Nosema cuniculi infection in laboratory rabbits. J. Amer. vet. med. Ass. 1969, 155, 1108-1114.

Landsverk $T$, Bratberg $B$ : Polyarteritis nodosa associated with sarcocystosis in a lamb. Acta vet. scand. 1979, 20, 306-308.

McCully RM, Van Dellen AF, Basson PA, Lawrence $J$ : Observations on the pathology of canine microsporidiosis. Onderstepoort J. vet. Res. 1978, 45, 75-92.

Mohn SF: Experimental Encephalitozoonosis in the blue fox. Clinical and serological examinations of affected pups. Acta vet. scand. 1982, 23, 503-514.

Mohn SF, Nordstoga K, Krogsrud J, Helgebostad A: Transplacental transmission of Nosema cuniculi in the blue fox (Alopex lagopus). Acta path. microbiol. scand. Sect. B. 1974, 82, 299-300.

Mohn SF, Landsverk $T$, Nordstoga $K$ : Encephalitozoonosis in the blue fox - Morphological identification of the parasite. Acta path. microbiol. scand. Sect. B 1981, 89, 117-122. 
Mohn SF, Nordstoga K, Moller OM: Experimental encephalitozoonosis in the blue fox. Neonatal exposure to the parasite. Acta vet. scand. 1982, 23, 211-220.

Montrey RD, Shadduck JA, Pakes SP: In vitro study of host range of three isolates of Encephalitozoon (Nosema). J. infect. Dis. 1973, $127,450-454$.

Moller T: A survey on toxoplasmosis and encephalitozoonosis in laboratory animals. Z. Versuchstierkd. 1968, 10, 27-38.

Nordstoga $K$ : Nosematosis in blue foxes. Nord. Vet.-Med. 1972, 24, 21-24.

Nordstoga K, Westbye Kr: Polyarteritis nodosa associated with nosematosis in blue foxes. Acta path. microbiol. scand. Sect. A. 1976, 84, 291-296.

Pakes SP, Shadduck JA, Cali A: Fine structure of Encephalitozoon cuniculi from rabbits, mice and hamsters. J. Protozool. 1975, 22, 481-488.

Pang VF, Shadduck JA: Susceptibility of cats, sheep, and swine to a rabbit isolate of Encephalitozoon cuniculi. Amer. J. vet. Res. 1985, 46, 1071-1077.

Petri M: Studies on Nosema cuniculi found in transplantable ascites tumours with a survey of microsporidiosis in mammals. Acta path. microbiol. scand. 1969, Suppl. 204.

Poonacha KB, William PD, Stamper RD: Encephalitozoonosis in a parrot. J. Amer. vet. med. Ass. 1985, 186, 700-701.

Robbins SL, Cotran RS: Pathologic Basis of Disease. 2nd ed. W. B. Saunders Company, Philadelphia, London, Toronto, 1979.

Shadduck JA, Pakes SP: Encephalitozoonosis (nosematosis) and toxoplasmosis. Amer. J. Pathol. 1971, 64, 657-672.

Shadduck JA, Bendele R, Robinson GT: Isolation of the causative organism of canine encephalitozoonosis. Vet. Pathol. 1978, 15, 449-460.

Van Dellen AF, Botha WS, Boomker J, Warnes, $W E J$ : Light and electron microscopical stu dies on canine encephalitozoonosis. Cerebralvasculitis. Onderstepoort J. vet. Res. 1978, 45, 165-186.

Van Rensburg IBJ, du Plessis JL: Nosematosis in a cat: A case report. J. S. Afr. vet. med. Ass. 1971, 42, 327-331.

Wilson JM: The biology of Encephalitozoon cuniculi. Med. Biol. 1979, 57, 84-101.

\section{Sammendrag}

Patologiske forandringer $i$ hjerne og ryggmarg ved encephalitozoonose hos blårev.

De patoanatomiske forandringer i sentralnervesystemet ved encephalitozoonose hos 11 naturlig infiserte blårever beskrives. Immunoperoxidaseteknikk ble benyttet til påvisning av parasittene og til identifisering av vertsceller. I alle tilfeller med akutte og subakutte forandringer påvistes en granulomatøs meningoencefalomyelitt og vaskulitt, med arterieforandringer som tilsvarte polyarteritis nodosa. I de kroniske stadier var forandringene dominert av arteriosklerose, perivaskulære mononukleære infiltrater, gliose og moderat granulomatøs reaksjon. Parasitter ble nesten alltid påvist $\mathrm{i}$ forbindelse med aktive betennelsesprosesser både $\mathrm{i}$ kar og hjernevev. Parasitofore vakuoler (PV) opptrådte $\mathrm{i}$ endotelceller $\mathrm{i}$ alle typer av kar og i tunica media i arterier. Parasittene viste stor affinitet til neuroner og fantes til og med i deres utløpere, noe som kan forklare at hjerneforandringene er så framtredende ved encephalitozoonose hos blårev. PV påvistes også i ependymceller i plexus choroideus og noen ganger i makrofager. Et stort antall parasitter forekom i fagolysosomer i makrofager. Dette kan tyde på at de er forholdsvis resistente mot nedbryting, noe som kan være grunnlag for utvikling av granulomatøs betennelse. Det konkluderes med at bortsett fra i kroniske stadier ved mild infeksjon, antas hjerneforandringene å være patognomoniske for encephalitozoonose hos blårev.

(Received October 13, 1986).

Reprints may be requested from: Inge Bjerkås, Department of Pathology, Norwegian College of Veterinary Medicine, P. O. Box 8146, Dep., N-0033 Oslo 1, Norway. 